IdeAs

Idées d'Amériques

$11 \mid 2018$

Modernités dans les Amériques : des avant-gardes à aujourd'hui

Managing Defense after History's End: A

Conversation with Robert F. Hale, Assistant Secretary of the Air Force during the Clinton administration

Gestion de la défense après la fin de l'Histoire: Une Conversation avec Robert F.

Hale, secrétaire-adjoint de l'armée de l'air pendant l'administration Clinton

Michael Stricof

(2) OpenEdition

Journals

Electronic version

URL: https://journals.openedition.org/ideas/2915

DOI: $10.4000 /$ ideas.2915

ISSN: 1950-5701

Publisher

Institut des Amériques

Electronic reference

Michael Stricof, "Managing Defense after History's End: A Conversation with Robert F. Hale, Assistant Secretary of the Air Force during the Clinton administration", IdeAs [Online], 11 | 2018, Online since 20 June 2018, connection on 20 October 2022. URL: http://journals.openedition.org/ideas/2915 ; DOI: https://doi.org/10.4000/ideas.2915

This text was automatically generated on 20 October 2022

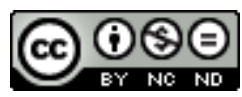

Creative Commons - Attribution-NonCommercial-NoDerivatives 4.0 International - CC BY-NC-ND 4.0 https://creativecommons.org/licenses/by-nc-nd/4.0/ 


\section{Managing Defense after History's End: A Conversation with Robert F. Hale, Assistant Secretary of the Air Force during the Clinton administration}

Gestion de la défense après la fin de l'Histoire: Une Conversation avec Robert F. Hale, secrétaire-adjoint de l'armée de l'air pendant l'administration Clinton

Michael Stricof

\section{About the Interview}

1 Robert F. Hale was Assistant Secretary of the Air Force (Financial Management and Comptroller) for the majority of the Clinton administration. In this conversation he offers perspectives on a variety of important topics for 1990s defense management, from the specifics of financial management reform in an era of declining budgets to broader questions of justifying the military after the Cold War. Political considerations ranging from the structural (Senate confirmations) to the specific (changing balance of defense dollars with the 1994 Republican takeover of Congress) round out the discussion.

\section{Note on the transcription}

2 This interview was taken by Michael Stricof on 13 September 2016 at the Booz Allen Hamilton offices in McLean, Virginia. This is a slightly modified transcript of the original recorded interview. Some sentences were cleaned up for clarity when reading, however these were minimal modifications not intended to eliminate the sense of 
spoken word. Redactions have been made at the request of the interviewee. Footnotes appear as occasional explanatory notes for potentially obscure references, while frequently used abbreviations are defined in brackets. Some off-topic chatter between the interviewer and interviewee, especially at the beginning and end of the recording was not included.

\section{Interview with Robert F. Hale}

[Michael Stricof] (Q): Thank you for sitting down with me. Normally, I just ask you to introduce yourself and give me your background, education, and then we'll move from there.

Robert Hale (A): I'm Bob Hale. Professional background: I worked for Congress for a number of years in the Congressional Budget office [СBO], then moved to the Department of Defense [DoD] as the Air Force comptroller in 1994, which I think is the focus of this discussion. I had some time outside of government, heading the American Society of Military Comptrollers for a while, but then went back as DoD's comptroller in 2009. I stayed there until 2014, and then came here to Booz Allen. I have a Bachelor's degree from Stanford, a Master's degree also from Stanford and an MBA from George Washington University.

Q: How did you get started in public service, originally?

A: I grew up on a fruit farm in California and that was about as far from the military and public service as I think you could be. But, I graduated from Stanford in the middle of the Vietnam War and there were sort of two choices: you could go to Canada or you could go in the military. So, I joined the Navy and they got me back to Washington, DC where I met my wife. Like so many career things it was happenstance that brought me into public service. But that said, it's been a great career and I'm certainly glad I ended up being back here.

7 Q: How did you get started working for the $\mathrm{CBO}$ ?

8 A: I was working-The Navy kicked me out, having essentially drafted me; I wasn't drafted but effectively drafted as a volunteer; then the Vietnam war ended-I went to work for the Center for Naval Analyses, a think tank organization here. I was kind of bored and frankly I saw a write-up of the new Congressional Budget Office in Business Week and said, "this is worth trying," so I sent them a resume, and they hired me.

$\mathrm{Q}$ : This was the late seventies? members or close to.

Q: Can you tell me a bit about the process for becoming Air Force comptroller?

A: Well, CBO got me involved in defense financial management and in policy analysis. But I wanted to be somewhere where I could manage something and do something about it as opposed to writing about it. CBO is basically a staff support agency, and it's a great place to work but I wanted to do something else. I had had my eye out for a political appointment for a while. It was a period of time where the Republicans were doing well and I'm a Democrat so I spent a long time at $\mathrm{CBO}$, longer than I had planned. But when the opportunity came around I was actively looking for a job in DoD.

Q: Who did you contact then? 
A: At the political level it's more that they contact you. I had friends who I had worked with, in particular John Hamre who was the [DoD] comptroller in the early part of the Bill Clinton administration. I think it was him that brought me over, really.

Q: Can you tell me a bit about the appointment process? It seems like there was a gap between your service at $\mathrm{CBO}$ and the Air Force.

A: It's-I would say it's exciting, chaotic and frustrating. First off, it was a long time before the White House and DoD made up their mind to offer me this position. It always takes time, but it took a long time, in that case. The election was in '92; Clinton of course was inaugurated in early ' 93 . They didn't contact me until October of ' 93 and even then it took about 5 months to get confirmed. You know, some of it's just waiting around. These aren't, you know, positions that are at the highest level, so they don't always move quickly and Congress took a while to get a hearing. Then, a Senator Ford who was from Tennessee at the time decided he wanted more C-130 aircraft-they're little prop planes that fly stuff around for the military-and a guard base in Tennessee. So he put a hold on my nomination saying, "If the department could get me more C-130s he'd let me go." That took several months, so all in all, I wasn't actually sworn in until March of '94.

\section{Q: Did he get the C-130s?}

A: I think he did. Yes. I mean, he had holds on all the DoD people, as did others. And they sort of brought them all together on one person and then I think basically made a deal.

Q: As comptroller for the Air Force then your primary work was preparing a budget estimate, or do I have that wrong?

A: Well, you have overall policy guidance for financial management in the Air Force, so it's more than the budget, although that's the primary job. It's overseeing the budget process that involves much of the Air Force and including levels above me up to the Secretary of the Air Force and the Chief of Staff. But you're also responsible for the day to day financial management, including work on things like auditable financial statements. And you're kind of a daddy rabbit for a career force, which was at that time about 10,000 people, as I recall, all spread out around the world doing financial management for the Air Force. They're not working for the Assistant Secretary directly, but you're kind of the head dog for that policy, so I did a lot of traveling to Air Force bases.

Q: When you were finally confirmed what were the major issues that you had to deal with right away?

A: Well, the budget is always the major one that faces any comptroller. It's got a laid out process, I don't know if you want to get into now or later?

Q: We can get into it.

A: So the Air Force, and all the services and OSD for that matter, have a pretty extensive process for putting together budgets. It starts at their bases, which do operating budgets, essentially. Then it flows up to their major commands where the issues get broader and bigger. There's a committee that reviews and makes recommendations then the Commander makes recommendations to headquarters and then there're several review committees including a senior one that I served on personally while I was in the Air Force. 
The senior level review committee makes a recommendation to the Chief of Staff and the Secretary of the Air Force, and they make the final decision. But then the Air Force budget goes to the Office of the Secretary of Defense, along with all the other services and agencies, and there's a fairly extensive review process that I headed when I was OSD comptroller that puts together an overall budget and that eventually goes to the Office of Management and the Budget [OMB] and they incorporate it in the President's budget.

It is a lengthy process. The long term planning can start as much as two years before the budget is really put together. But there is a focus on the budget for about a year before it's submitted and then there's a Congressional review and finally the execution.

The Air Force was coming down sharply in size, and the Cold War had effectively ended in 1989. I looked up the numbers and in 1988 the Air Force had 576,000 people on active duty. By the time I came in in 1994 that was down to 426,000 and when I left in 2000 it was about 350,000 . So they were coming down, not quite half, but probably by $40 \%$. In that period there was also a lot of effort to figure out what their mission was in the post-Cold War era. None of that was really clear in the early 90s. I think it has kind of shaken out by now. I remember when I was working at the Congressional Budget Office in 1989 when the wall came down, my boss there said, "Well, what are you going to do now we won't need a military anymore." I wish he had been right. Hasn't worked out that way. So, the issues, the major ones were how do you do the drawdown? ${ }^{1}$ How far do you go? What do you keep? I wasn't making all those decisions, by any means, but I was participating in the process as they were being made.

I also realized that the 1994 Congress passed a law that DoD has pretty much ignored until recently requiring auditable financial statements for all major federal agencies, called the Government Management and Reform Act. The Air Force wasn't doing anything, and DoD wasn't doing anything. I tried to get started, and there was a lot of pressure on the department to do something. Trying to get started in the Air Force, I had mixed success at best. DoD still doesn't have auditable statements, but I had more success as OSD comptroller because I had a lot more power. Still, I spent a fair amount of time on the financial management side in the 1990s. It was a workforce that was kind of dispirited because of all the drawdowns. They were getting smaller; people were being let go. As I said, I did a fair amount of traveling. This also served to reassure the workforce that the Air Force was going to be there. It'd be smaller and their organizations would be smaller but the mission still remained.

Those were the major legs of the stool of my efforts as Air Force comptroller.

Q: Getting into the drawdown then. Had most of the major decisions been basically made before you took office?

3 A: No. Some of them certainly had. As I said, they'd come down by one hundred and some odd thousand. Which meant getting rid of a lot of units. But they had another roughly 100,000 to go, or $70-80,000$ to go. And that occurred during the 90 s. The 90 s were a tough period. Bill Clinton's focus wasn't on the military. He was definitely a domestic president. I won't say he ignored the military, he didn't, but it wasn't his focus, and it wasn't his budgetary focus, either. So we were making budget cuts for most of the early portion of my tenure in the Air Force, before they mostly leveled off toward the end. We had large surpluses by that point so there wasn't the same budgetary pressure. And it was clear the military was underfunded. We weren't 
spending enough on the bases, we weren't modernizing to the degree that was needed. Needs were arising, so the budget leveled off. Still, it never really grew much during the [late] Clinton years. Of course 9/11 came shortly after he left and they soared.

Q: Right. In terms of decision-making: you just said that while you had something of a role, it wasn't so much in a decision-making capacity. In terms of what would be cut and when, how were these decisions ultimately being made? It wasn't the primary focus of the administration, but there had to be efforts coming from somewhere.

A: Well, no, they were being made. The Department is huge; the Department of Defense is a huge organization. The Air Force is huge. It's got thousands of decisions made in a kind of pyramid manner, if you will. At the bottom of the pyramid you've got the bases and some of the major commands making a lot of the smaller decisions about how much they're going to fly for training and where. Certainly those kinds of operational decisions were made outside the Pentagon. When it gets to the headquarters of the Air Force they're more worried, I think, about the modernization program: how does it all add up, because it's usually adding up to more than the likely budget for the Air Force, so they've got to start trimming. This is certainly one of their major goals, along with any large changes of direction. Although by ' 94 they were already heading in the drawdown direction, so I wouldn't say there were any large changes.

So, the smaller decisions get made by the bases and the major commands. The medium sized ones at the Air Force level. And the big issues get made by the Secretary of Defense during the review, at the level of the Office of the Secretary of Defense.

Q: How often are these reviews undertaken?

A: Every year. They do an annual budget and a 5-year plan, but the focus is on the first year of the 5-year plan, which is the budget year. So it is an ongoing process and in fact a heavily overlapped process. As I said, the early planning for the budget starts at least two years before it's even submitted to Congress, so you're working on multiple budgets simultaneously. Not to mention the fact that you're executing a budget at the same time. There's a fair amount of money moving around, and the comptroller gets pretty heavily involved in responding to that. Then you get things like the Bosnian conflict, and you know, certain commands are going to need more money. You usually can't just do that, you have to go back to Congress and ask them for authority to move the money. So there's a fair amount of internal or execution kind of work going on, much of which is done by the comptroller organization.

37 Q: Getting into Congress then: what pressures were you feeling, either directly or flowing down from higher up the hierarchy from Congress in this period?

38 A: Well, Congress was of two minds. There were a number who were quite happy with the drawdown. It freed up funds for what a number of especially Democrats viewed as higher priorities in the domestic arena. But, as cracks started to appear, as readiness wasn't what it might have been, as the bases weren't being maintained as well as they should be, I think, especially some of the Republicans started pushing hard for increases in the budget. So we heard from both sides of that.

39 But I should say something about Congress and the services: especially the senior civilian leaders in the services don't have heavy contact with Congress on the budget. It's done largely out of the Office of the Secretary of Defense. Some of the senior military leaders do because Congress likes to talk to the military, so they'll want to hear 
from the Chief of Staff and some of the senior leaders, but not so much the senior civilians.

Now when I got to OSD it was a very different story. I was constantly working with Congress either on the Hill or dealing with them because OSD does most of that, but less so in the Air Force. I think I only testified a few times, even in seven years, a handful of times. And mostly on things like audits, improper payments, financial management and problems, as opposed to the real budget. In contrast, I testified maybe 40 or 50 times, including joining the Secretary of Defense and the Chief of Staff when I was at OSD as a backup witness during their main budget testimony. So, not as much involvement on the Hill and certainly nothing like what happened at OSD.

Q: Fair enough. Still it's also illustrative to see what happens at OSD. Did you hear much from the administration or the Office of Management and Budget, or did that still flow through the Secretary of Defense?

A: Well almost all the liaison with OMB is handled by OSD. Very little contact with military or civilians. I mean occasionally, but not much. So, I was constantly in touch with OMB as OSD comptroller, not very much as the Air Force comptroller. The same for CBO. I had been at CBO for 16 years and was aware of their studies. But, as the Air Force comptroller, there wasn't any day-to-day contact like when I was in OSD, except on a personal level.

Q: Okay, fair enough. Why don't we get into some specifics from the period? I'm just going to go through basically the questions I had sent you in order but if there's something else that jumps in we can cut out.

Did the government shutdowns have an effect-

A: [laughs] Yes.

$\mathrm{Q}$ : Can you tell me a bit about that?

A: Well, there were actually two shutdowns. I had to refresh my memory on this one, too. I sure do remember the 2013 one intimately because I oversaw that process for DoD. There were two shutdowns [in 1995], one occurred in November for almost 10 days; I wrote down the dates somewhere, for 6 or 7 days. DoD was shut down because we didn't have an appropriation. The absence of appropriation generally generates a shutdown, and then there is a very limited number of things you can legally do. Essentially you can take actions to protect property or ensure the safety of life. DoD interprets that pretty broadly, and is allowed to. So all the ongoing military operations, named military operations, were allowed to continue. We probably had close to half our civilians and essentially all of our military working. But you were constantly confronted by the question: can I do this legally or not? So, it was a very busy period. Political appointees are exempt from the shutdown, so I was working. It was not nearly as chaotic and busy for me as the sixteen days in 2013 [laughs].

48 There was a longer second shutdown that occurred from mid-December to Januaryfrom December 15th, '95 to January 6th, '96. It didn't affect DoD because we got an appropriations bill. So, we were basically trying not to be smug, but were going about our normal business during that one, which was long and difficult for the civilian agencies.

Q: Along similar lines, was there a shift in priorities or pressures after the midterm elections? 
50 A: Well, we were basically in the executive branch, but obviously Congress has an important role to play and as the Republicans took over, I think there was more pressure in favor of higher defense budgets. Republicans generally favor higher defense budgets. They certainly did during that period of time, so there was more pressure from them to increase the budget. This is awkward for the political appointees in the military. Of course we'd be very happy to have more money, but we also work for the president. So in the end there is a certain amount of awkwardness.

51 Q: Interesting. Similarly, although this might have fallen before you took office, but the handling of early Clinton interventions/non-interventions in Somalia, and also Haiti-

52 A: Yeah, well, Somalia occurred-that was Aspin's tenure. I wasn't there at the time. I was still at CBO. I can't remember when the Haiti one was.

Q: Well, there was a non-event in late '93 and then there was finally the actual, nonintervention, but political settlement like a year later. ${ }^{2}$

A: I mean, for the most part the financial management community doesn't get heavily involved in those events. I knew about them once I got there because I was in staff meetings where they were being discussed. But it wasn't a part of my day-to-day life. In contrast to something like the Bosnian war where we were moving money around constantly to try to support it. There, there was day-to-day financial involvement.

Q: Why don't you tell me a little bit about that, then, how the money actually gets shifted.

56 A: Yeah. First, you get an appropriation from Congress. It's in pots of money. They're fairly small. Although the operating pots are bigger than the modernization pots, and it's the operating dollars that are at issue when you find yourself going to war. Some command is flying a lot and so they're going to need more money. You have to find sources for that. And then follow the rules: for small transfers you can do them without Congressional approval so long as Congress hasn't specifically said, "Don't do this". For larger transfers you have to go through a process called reprogramming, where you go to the Hill and say, "Here's what I want to do: I want to move money from A to B, is that okay?" and all the committees have to approve it. It's a time consuming process, both in terms of justifying it and getting it through all the wickets. But an absolutely critical process, especially if you find yourself in war.

57 The 90s were calm compared to what we went through in those five years when I was the OSD comptroller. We were moving 8-10 million dollars a year, and it raised a lot of eyebrows on the Hill. But I was up there saying, "Guys, we're in a war. And you've got to let me do this or we're not going to be able to support the troops." Well, "grumble grumble, why didn't you think of it?" "Cause I'm not foresighted enough to predict a war two years in advance?" Well, I didn't say that, but these things were understood. So, day-to-day involvement.

58 Still, it was interesting to sit in the staff meetings even though I wasn't involved in some of them. I particularly remember the Bosnian conflict when they were very concerned about getting munitions to where they needed them. And I remember a couple of staff meetings where the Chief of Staff of the Air Force was almost down to saying, "Okay, where is this ship right now and what exactly does that one have?" or "When's it going to get there?" Because they were so concerned about running out of the kind of munitions that they needed to pursue the air war in Bosnia. Money wasn't a 
big issue at that point. I mean, we just made sure they had enough money to pay the ship costs, but that was small. But the logistical problems were significant.

Q: Do you think those were just from the specific experience it was, or were they exacerbated by the previous drawdown or reductions?

A: Probably some of both. Certainly, it was brought about because nobody can know in advance exactly what you're going to need and where you're going to need it. That was the major problem. But the drawdown had meant purchasing fewer munitions. They tend to cut back buying munitions when they're not in a war time period and trying to drawdown budgets because they're trying to keep the big ticket stuff going. So I suspect we bought fewer of them. And we used a fair number of them.

We're having even bigger problems now. They're running short of, especially some of the expensive precision-guided munitions, and are screwing around buying them as quickly as they can because they're using them so heavily in places like Syria.

Q: So here's something I want to pinpoint, as long as we're on the subject, you said it seems typical you cut munitions and not big ticket items. Is there is a reason why that's the case? Why you would cut munitions rather than bombers for example?

A: Some of it I suppose is simply that it's probably the lazier option. You're buying hundreds of munitions, usually. In a drawdown, if you're buying 250, you can go down to 200 or even 175 and, it's probably not efficient, but the production lines are going to continue. They're not going to close down. If you're only buying a couple dozen jets, you don't want to cut back very much because you really will have effects on the line. Munitions are really the pointy end of the spear for the military, so in the end they'll probably buy the munitions because they know it's not useful to have the planes without something to arm them with. But, if they can't see that problem at hand they're going to keep buying the big stuff. If you look at it, about $50 \%$ of DoD's modernizations budget is smaller items. It's not anything that most people would know about. The other half are the big ticket items. If you look at the cuts in what I call nonmajor procurement, they're always larger during a drawdown period.

Q: I feel like that would adversely affect readiness more than some other things, but-

A: Well, I mean, they can't go too far. And I suspect-I haven't looked at it recently-I suspect, I know we're buying more munitions because I just said they're running short of some of them and I think they realized how important they are. But you know, when you're in the 90s, we didn't fight much, fortunately. Bosnia was fairly short, and those other interventions were tiny. Nothing like what happened in Iraq and Afghanistan. When you're in a period of relative peace, you know, there's a tendency to say, "well, we can cut that line back for a couple of years and make sure we buy more F-16s" for example. It's probably not a bad decision; you just can't go too far. I feel like you must have had your finger on the pulse of that a little bit, in that particular period.

A: Well, the Air Force is usually run by fighter pilots. So aircraft are certainly a key. I think there was a growing realization that we can't fight without satellites anymore, especially all the communications satellites with GPS. But it's not called the Air Force for nothing. I think aircraft are still the primary thing. Probably fighters. But the people running the Air Force, although they may be fighter pilots and their heart is in a cockpit, they understand that you need a balance of forces. So for example, right now, I 
think if you ask the Air Force, they would have said-at least until a couple of years ago when the F-35 fighter came along-their highest priority was the tanker. Our tanker fleet, the aerial refueling fleet, was getting quite old. We're buying a new tanker, the KC-46, and they would have said it's their highest priority aircraft because they understood they needed it to fight and all of the services do. So I mean, they're responsible, but their hearts are in aircraft, which are probably the highest priority.

Q: Getting into some technology questions as you mentioned GPS. I have this impression that in the 90s there was a faith in high technology, as if it were going to save everything.

A: Well, I don't know about save everything, but there was a realization that it gave substantial capability. I mean, GPS is a good example. It revolutionized not only the military but the way we all live actually. I used to joke as the comptroller, "If I could just charge a user fee for GPS I could finance the Air Force out of it," and I probably could. And the Air Force is a pretty high tech service. They'll always say that people are the key, and I think they believe that, but they also recognized that advanced weaponry helped to keep ahead of prospective enemies.

70 In the 90s, that very issue was being called into question: who is the near peer competitor? The Russians? Their military was decaying to some extent. Not probably as much as people think, but it was. And China hadn't begun its march toward a more sophisticated military, so there were a lot of questions being raised. "Who are you buying all this stuff to fight?" And I think the answers were mixed. And that's part of the reason the military budgets didn't fare so well.

71 Unfortunately these days, you know, if we're not back in the Cold War we're in a hot war, unfortunately. And the Russians are spending and the Chinese are frightening, and it's such a big country. Give it ten or fifteen years, if it decides that what it wants is to have the world's best military they'll give us a run for our money. They're certainly not there now, but they're coming along. They started stealth fighters. They're several generations behind us, but they're going to make up, and they can steal a lot of what we know and use it so they'll catch up quickly. I hope we don't ever have to fight the Chinese, but unfortunately, I'm afraid that we'll certainly end up in military confrontations with them I fear.

Q: Scary thought.

73 A: Yep.

74 Q: Did broader administration goals of acquisition reform or the reinventing government movement affect you at the Air Force level?

75 A: I think they probably were handled more at the OSD level. I don't want to sound cavalier about this, but we've been reforming the acquisition system it seems constantly for my entire career which now goes back over 4 decades. It's hard to point out major changes. If you ask me to point to something that occurred during the $90 \mathrm{~s}$ that I actually think tangibly improved acquisition it would be the purchase card. In the early 90s, the military was using paper acquisitions. You want to buy a can of paint, you had to go to a contracting officer and get a form, a paper form, and you'd take it to a seller they had a contract with, then you give the store the paper form and they submitted a bill and they got paid later. I mean, it was a very inefficient process, with huge contracting workforce and paper flying all over the place. They introduced the purchase card, which is a credit card that is given to certain people who have authority 
to purchase, but a large number. And they can go to wherever they want and buy up to $\$ 2500$ unless they've got special authority. And, you know, it just drastically cut down the paperwork. Because all the big stuff was all still done by paper. But all the little stuff, you could get it faster and everybody loved it.

The only problem is that a few people misused the thing to buy for personal use. Some of them-one story, I can't remember. They also introduced a travel card at the same time, a Visa card. And everybody had that, and there were a lot of problems there. You get 18 year olds and most of them are going to be fine, but a few of them went out and, you know, paid for whores with it or something. I mean, we had all kinds of problems with it.

But that purchase card, I think, has fundamentally saved money.

As did the travel card. We used to do everything with cash. I remember visiting bases in the Air Force. They'd have a million to two million dollars in cash in their vaults. And this is in the 90s so that's probably twice that amount now. Now they probably have none. Or they have a few hundred dollars for real emergencies maybe. Of course, if you have two million dollars sitting there you've got to have people to take care of it. You've got to have somebody to be logging that money in and out. It's got to have security. So we had a lot of people handling cash. All of that's gone now. So, I think the travel and purchase cards, and in terms of acquisition reform, the purchase card, were one of the few things I can really point to and say absolutely that was a good idea.

$\mathrm{Q}$ : When were those introduced?

A: Early 90s. John Hamre was the comptroller at the time and he was-I don't remember the exact date-he was pushing their introduction. Frankly, the military leaders hated them because-and I can't blame them-when somebody misused the card then the base commander or his legal staff had to get involved and now there's a trial-like process, if it was a serious misuse. There were some funny situations, too. I remember this story, I think it was Arizona. Anyway, they got a report that somebody had gone to a bar and bought a horse with a purchase card.

Everybody said, "Oh Shit!"

Well it turns out that-I forget some parts of this story-they were trying to work with the Border Patrol and they couldn't use cars for some reason. You've got to do whatever they were going to do on a horse. The guy said, "Okay, I know a guy that's got a horse, let's go to the bar over there, we'll sign the paperwork over there, I'll give you my purchase card and so" [laughs]. It turned out it was an entirely legitimate transaction. But, you know. I think most private companies were a lot easier going about this.

Q: Interesting. Otherwise you didn't feel like there was much impact from-

A: I didn't notice it.

Q: Even from the middle of the service level, not much notice?

A: Yeah. You know, when I came into being the Air Force comptroller, I really only knew the budget. I didn't know much about financial management. I quickly realized that I could probably do more to help the Air Force financial community by working some of the financial management, that is, the execution issues. I certainly paid attention to the budget but there are a whole lot of people that were paying attention to that. There were a lot fewer paying attention to execution. So I tried to put in place 
some new systems to help handle some of the transactions in a more automated manner. We set up an organization that provided advice, it was kind of a center where managers could go for advice on particularly difficult issues. They could phone somebody and try to resolve a lot of the small problems in financial execution we were having.

A: Oh, improper payments. The government is-this is overly simplistic to say it-but fundamentally if you're in the private sector you can do anything, financially you can do anything that you want unless it's illegal. In the government it's kind of the opposite. You can only do it if it's legal; that is, if Congress has passed a law. That's a little simplistic, because obviously they pass so many laws that are broad and they don't revisit every transaction by any means. But it's a fundamentally different mindset. So, we'd get into situations where people had either misused a travel card or a purchase card or the bookkeeping processes. We were pretty paper oriented in the 90s -they're much more automated now-so mistakes would happen. Somebody would mispost a transaction to a certain account. And then the real transaction came in and essentially overdrew the account. That's called a "negative unliquidated obligation" or NULO-sounds like some kind of African animal. So we were looking for ways to streamline our handling and cut down on the errors so we had fewer of these things. And we had billions of dollars of accounts that were overdrawn. When you did all the research generally it turned out "oh yeah, that's a wrong transaction, it should have gone over there," and then everything was fine, but somebody had to take the time to sort through all the paper. DoD does about 150 million accounting transactions a year. And the Air Force probably does, oh, 30 or 40 million. When you're doing those kinds of volumes even a 1 or $2 \%$ error rate is a big problem. And sometimes the error rates were higher. You had to have a huge staff sorting all this stuff out. So we were looking for ways to cut down on the paperwork and reduce the number of errors. We had some success. They're having more now.

Q: In terms of these reform effort, and going along with these other points, you mentioned in terms of construction of the budget, your comments make this sound like a bottom-up process: you start with the bases and their requests and it works its way up to OSD and they send it off. In terms of transformation within the services how does that function?

A: Well some of it was bottom-up. I use to say to the bases, "Look, guys, everything doesn't have to be some grand thing from headquarters. If you figure out a better way to fix aircraft or to maintain them, you know, less rework, etc. you've got to do it." But the major changes tended to be top-down, because they usually require legislative approval. Which meant that somebody in Washington was going to have to work with Congress. If it's bigger, it's going to affect the whole Air Force or the whole of DoD, it tends to be top-down.

91 Q: And did reforms permeate sufficiently?

92 A: Yes and no. One of the biggest problems is in an organization: it sounds like you just tell everybody to do it, it'll happen. Well that's just not true. People don't like to change, especially if it's a change that they didn't propose or that doesn't seem to help them. I'm trying to give you an example, and I'm going to have to draw on something a little more recent. 


\section{(1)} ten years, DoD has been trying hard to do something called strategic sourcing. Essentially, it's a fancy word that says they gather together all their purchases. If you're purchasing certain kinds of IT equipment and you can go to a single or a couple of vendors with huge orders you're going to get a better price. Purchasing tends to be done in a disaggregated way at the lower commands; they're all out doing their own thing. For example, that purchase card causes wide dispersion among businesses. And that's not all bad. But if you think you can save a lot of money, then you've got to get everybody together and say, "Okay, we're all going to buy from one contract and/or a couple of contracts and we'll compete it at the Air Force level." Well no one really wants to do that because now they don't control exactly what they get, and they kind of liked the vendor they had, and I mean, they had a personal relationship. It's very difficult to get people to do that. Closing down service centers is another example. DoD has an incredible number of service centers. I want to say it's hundreds, if not thousands. And it doesn't make any sense. I mean you want to have enough so you've got redundancy, but it's much more efficient to operate a dozen big ones than a hundred medium or small ones. But people don't want to lose their service center, "Well, then how do I know I'm going to get that service?" So those kind of things have to be top-down, and they're difficult to implement.

95 People ask why government isn't efficient. That's part of the reason. Although I see some of that in big companies too. You know, everybody kind of wants their own. I had a good friend who is a vice president at Exxon Mobile. When I would describe the kind of things that I was describing he said it was same thing at Exxon. Everybody wants their own servers. They want their own thing; they want to control their own. The difference is though there's a boss and if they ever get into profit problems, they're all going to change in order to protect the company. It's not going to happen at Exxon but at other companies. DoD never really had profit problems. Modest problems of budget cutbacks. But, nothing like a company going through a transformational experience.

Q: Fair enough. Were there any key pieces of top down legislation or administrative guidance that you felt really had an effect in your time there?

A: Ehhh...Well, the budgets obviously. I know that's not what you're looking for. DoD runs with budgets. And the fact that they were coming down in real terms significantly affects almost everything we did. I can't think of a single piece of legislation that in the financial area at any rate that had those kinds of effects.

If you look at the history of the defense budget. If you put it in constant dollars back to 1950. It's a roller coaster pattern with peaks, usually wartime periods-Vietnam, Iraq, Afghanistan. The Reagan era was the exception because there was a peak there, even though that was a period of relative peace. And there are an equal number of valleys. And we're talking about one of the valleys in the 90s.

99 I would argue that the budget is driven basically by threats to national security and foreign policy.

100 You know, in the good times, you fix all the bases. In the early 2000s all of a sudden they went from not having enough money to the bases looking great. Right now we're going right back down the same path again. They're starting to short them again. We're 
not spending nearly enough on military construction to keep up the facilities. You can get away with that for a while, but you know, we're headed back in the same direction.

Q: That always seems to be a recurrent theme. Obviously this is a bit glib, but the only good thing about war is the construction budget you end up getting.

A: Well, it's true. You know, it's not a good reason to have one, certainly. I wonder if we're going to have periods without wars. It just seems...

You know I often think back: it was Bob Reischauer, who headed the CBO in the late ' 80 s, who made that comment to me, "what're you going to do now we won't need a military?" and how wrong he was. I never would have imagined that. However, I remember reading an article, "you're going to miss the Cold War," ${ }^{3}$ and thinking, "right, nine thousand missiles pointed at us." I don't know that I miss it, but things aren't all that much-militarily I think things are much more difficult now than they ever were during the Cold War.

\section{NOTES}

1. "Drawdown" is a regularly used term to describe post-war reductions within the Department of Defense. Can apply to smaller budgets, manpower or both. The 1990s were the post-Cold War drawdown.

2. USS Harlan County retreated from Haiti in October 1993; US negotiators reached a settlement to end the Cedras junta and return President Aristide to power in October 1994.

3. Reference to an article by John J. Mearsheimer, "Why We Will Soon Miss the Cold War," The Atlantic Monthly 266, no. 2 (August 1990): 35-50.

\section{AUTHOR}

\section{MICHAEL STRICOF}

Michael Stricof est doctorant contractuel « fléché Institut des Amériques » au Laboratoire d'Études et de Recherche sur le Monde Anglophone (LERMA, EA 853) d'Aix-Marseille Université, coordinateur du pôle Washington de l'IdA et chercheur invité à Georgetown University. Sa recherche porte sur la politique des dépenses militaires après la guerre froide. Sa thèse: « Les dividendes de la paix et la reconversion de la défense pendant l'administration Clinton, 1993-2001 » est sous la direction d'Isabelle Vagnoux. mstricof@gmail.com 